TOMASZ GUZIK ${ }^{1}$

\title{
Philosophical justification of copyright protection in regard to the international treaties and the EU law
}

\begin{abstract}
The article concerns philosophical justification and philosophical background of copyright protection relating to international treaties and the law of European Union. This paper is divided into three parts. The first one presents the regulation of copyright law on the international level. Moreover, the European Union's sources of copyright law are demonstrated. The second part concerns philosophical justification of the copyright protection. Various philosophical stands and concepts that can be helpful with better understanding of this branch of law are presented and explained. The conclusions on philosophical justification of copyright protection in regard to the international treaties and the EU law are shown in the final chapter.
\end{abstract}

Keywords: copyright protection; philosophy of law; European Union law; International law; International treaties; intellectual property law

Tomasz Guzik - PhD student, Jagiellonian University, Faculty of Law and Administration; e-mail: t.guzik622@gmail.com; ORCID: 0000-0002-5355-5910. 


\section{Filozoficzne uzasadnienie ochrony prawa autorskiego w kontekście traktatów międzynarodowych i prawa Unii Europejskiej}

\section{Streszczenie}

Artykuł poświęcony jest kwestii filozoficznego uzasadnienia oraz filozoficznego kontekstu ochrony prawa autorskiego w odniesieniu do międzynarodowych traktatów i prawa Unii Europejskiej. Praca podzielona jest na trzy części. Pierwsza część to omówienie uregulowania prawa autorskiego na poziomie międzynarodowym. Ponadto przedstawione zostały tam źródła prawa autorskiego obowiązujące dla Unii Europejskiej. Druga część pracy to filozoficzne uzasadnienie ochrony prawa autorskiego. Zaprezentowano i objaśniono tam różne perspektywy, koncepcje i poglądy filozoficzne dotyczące omawianej kwestii, które mogą być pomocne w zrozumieniu poruszanej tu dziedziny prawa. Wnioski dotyczące materii filozoficznego uzasadnienia ochrony prawa autorskiego w odniesieniu do międzynarodowych traktatów i prawa Unii Europejskiej przedstawione są w ostatnim rozdziale pracy.

Słowa kluczowe: ochrona prawno-autorska; filozofia prawa; prawo Unii Europejskiej; prawo międzynarodowe; traktaty międzynarodowe; prawo własności intelektualnej 


\section{Introduction}

Copyright protection as well as the whole intellectual property law is becoming a more and more important branch of law in modern society. It is because we are living in the "information era" when access to various fruits of human intellect is as easy as never before. Thanks to global network each of us can read handbook of quantum physics, Steven King's latest novel or article about weird psychological effect published in Science with only one click. With the increasing role of information and the higher demand for books, articles and other objects of the copyright protection, the importance of copyright law is growing. It has occurred since the printing revolution of Johannes Gutenberg. The possibility of capturing human thoughts and saving them in a durable medium gave people the opportunity to share their innovative ideas. Nowadays probably each adult civilian from the western civilization has heard about copyright. He or she may even know the basic assumptions of copyright protection. However, only some of those people have ever wondered what philosophical justification of copyright is. Philosophy is the "mother" of the whole science. Because of the philosophical reflection about the essence of our world, the present science could be born. This paper is divided into three parts. In the first one, the regulations of copyright law at the international level are very briefly presented. Further, the European Union's (in short: EU) sources of copyright law are also shown. International and the EU law contains legal norms that have to be implemented or applied by member states. Therefore, it is worth analysing the philosophical perspective of these sources of law. The second part focuses on philosophical justification of the copyright protection. There will be submitted and explained various philosophical stands and concepts that will help us to better understand this branch of law. In the final part, the author presents his own opinion and conclusions on the philosophical justification of copyright protection in regard to the international treaties and the EU law. 


\section{Legal framework}

\section{International law}

Firstly, it is important to present briefly sources of law relevant to the subject of this work. International Copyright system of law consists of a few significant sources of law. One of them is The Berne Convention for the Protection of Literary and Artistic Works (further: Berne Convention) signed in Berne, Switzerland, in 1886. ${ }^{2}$ This treaty was the first source of international law concerning the copyright protection. However, it was revised several times (e.g. 1948 Brussels Text or 1971 Paris Act). ${ }^{3}$ One of the most substantial principles included in the Berne Convention is the concept that all parties of the Convention shall apply the same approach towards copyrights of citizens of other parties as it would be in the case of their civilians. ${ }^{4}$ The second one is that copyright protection under this source of law is "mechanical”, thus - no formal requirement (registration or any other) is required. This provision is included in the art. 5 (2) of the Berne Convention. ${ }^{5}$

Another treaty that constitutes an international system of copyright law is the Universal Copyright Convention (further: UCC) signed in Geneva, Switzerland, in $1952 .{ }^{6}$ Preparations of this treaty were delivered under the UNESCO auspices. ${ }^{7}$ The main reason of creating the subsequent source of law was to construct copyright protection for those countries that were not parties to the Berne Convention ${ }^{8}$ including countries from Asia, Africa, a few Latin states and the United States of America. ${ }^{9}$ According to the legal content, this treaty contains (similarly to the Berne Convention) equal treatment principle in relation to published or unpublished works created by citizens of member states. ${ }^{10}$ The very interesting thing is the provision

2 The Berne Convention for the Protection of Literary and Artistic Works, http://www.wipo.int/ treaties/en/text.jsp?file_id=283698\#P85_10661 (access: 11.02.2018).

3 See more: P. Goldstein, International Copyright: Principles, Law, and Practice, Oxford 2001, pp. 19-20.

4 Art. 5 (3) of the Berne Convention for the Protection of Literary and Artistic Works, http://www. wipo.int/treaties/en/text.jsp?file_id=283698\#P85_10661 (access: 11.02.2018).

5 Ibidem.

6 Universal Copyright Convention as revised at Paris on 24 July 1971, with Appendix Declaration relating to Article XVII and Resolution concerning Article XI 1971, http://portal.unesco.org/en/ ev.php-URL_ID=15241\&URL_DO=DO_TOPIC\&URL_SECTION=201.html (access: 11.02.2018).

$7 \quad$ P. Goldstein, op. cit., p. 28.

8 Ibidem.

9 Ibidem.

10 Art. II (1) and art. II (2) of the Universal Copyright Convention as revised in Paris on 24 July 1971, with Appendix Declaration relating to Article XVII and Resolution concerning Article XI 1971, 
of art. XVII (1) which states that UCC "shall not in any way affect" legal articles of the Berne Convention or membership in the Union created by that Convention. ${ }^{11}$ However, due to immense impact (territorial and legal) of the World Trade Organization, and thus the Agreement on Trade-Related Aspects of Intellectual Property Rights Agreement, ${ }^{12}$ the UCC seems to lose its importance constantly. ${ }^{13}$

The last treaty that has global influence is the World Intellectual Property Organization Copyright Treaty (further: WCT) adopted in Geneva, Switzerland, in 1996 and administered by WIPO.$^{14}$ As art. 1 (1)-(3) ${ }^{15}$ shows that the treaty is strongly associated with the Berne Convention, in particular, with 1971 Paris Act. Paul Goldstein emphasized that the WCT focuses on three aspects of protectable subject matter under the 1971 Berne Paris Act: first, that computer programmes are protected as literary works under Article 2 of the Berne Paris Act; then, compilations of data are "protected as such"; thirdly, that "copyright protection extends to expressions and not to ideas, procedures, methods of operation or mathematical concepts as such". ${ }^{16}$

After explaining the fundamental regulation of international copyright system of law, then it is possible to bring the European Union Law (further: the EU Law) provisions closer.

\section{European Union Law}

First of all it must be stated that all member states of the European Union are also parties to the Berne Union. ${ }^{17}$ Thereupon, European Union copyright law may require the member states to offer more, but not less, protection than it is required by the applicable text of the Berne Convention. ${ }^{18}$ The reason why European Union began to create copyright rules is that it was as an attempt to harmonise the different

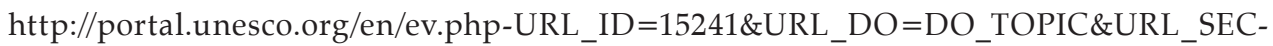
TION=201.html (access: 1.02.2018).

11 Universal Copyright... (access: 11.02.2018).

12 Agreement on Trade-Related Aspects of Intellectual Property Rights (TRIPS) is a source of international law that came into force in 1995. It is an international agreement between all member states of the World Trade Organization (WTO). It introduced standards of regulation of various types of intellectual property (IP).

13 See: https://en.wikipedia.org/wiki/Universal_Copyright_Convention (access: 11.02.2018).

14 WIPO Copyright Treaty, http://www.wipo.int/treaties/en/text.jsp?file_id=295166\#P45_2379 (access: 11.02.2018).

15 Art.1(1)-(4)of the World Intellectual Property Organization Copyright Treaty, http://www.wipo. int/treaties/en/text.jsp?file_id=295166\#P45_2379 (access: 1.02.2018).

16 P. Goldstein, op. cit., p. 33.

17 Ibidem, p. 36.

18 Ibidem. 
copyright regimes of the European Union member countries. ${ }^{19}$ Nowadays, the EU Law is composed of a number of Directives that must be enacted into national laws of the member states. ${ }^{20}$

I truly agree with the opinion that the attempts to harmonise copyright law in Europe in principle can be referred to the signing of the Berne Convention for the Protection of Literary and Artistic Works on 9 September $1886 .{ }^{21}$ This view is justified mainly because seven out of ten signatory countries came from Europe. ${ }^{22}$ At present, the following directives are in force as to the matter of copyright protection: Computer Programs Directive (1991 and 200923), Rental and Lending Rights Directive (1992 and 2006 ${ }^{24}$ ), Satellite and Cable Directive (1993), ${ }^{25}$ Term of Protection Directive (1993, 2006 ${ }^{26}$ and 2011), Database Directive (1996 $\left.{ }^{27}\right)$, Information Society Directive $\left(2001^{28}\right)$, Resale Right Directive (2001), ${ }^{29}$ Orphan Works Directive

19 S. Foreman, Copyright Law: World Study, Delhi 2012, p. 27.

20 Ibidem.

21 Ibidem.

22 As it is written in The Berne Convention, its Additional Article and its Final Protocol, those sources of law were signed by the following ten countries: Belgium, France, Germany, Haiti, Italy, Liberia, Spain, Switzerland, Tunisia, and the United Kingdom, http://global.oup.com/booksites/content/9780198259466/15550015 (access: 2.02.2018).

23 Directive 2009/24/EC of the European Parliament and of the Council of 23 April 2009 on the legal protection of computer programs (codified version), http://eur-lex.europa.eu/legal-content/EN/ ALL/?uri=CELEX\%3A32009L0024 (access: 11.02.2018).

24 Directive 2006/115/EC of the European Parliament and of the Council of 12 December 2006 on rental right and lending right and on certain rights related to copyright in the field of intellectual property (codified version), http://eur-lex.europa.eu/legal-content/EN/ALL/?uri=CELEX\%3A32006L0115 (access: 11.02.2018).

25 Council Directive 93/83/EEC of 27 September 1993 on the coordination of certain rules concerning copyright and rights related to copyright applicable to satellite broadcasting and cable retransmission, http://eur-lex.europa.eu/legal-content/EN/ALL/?uri=celex\%3A31993L0083 (access: 11.02.2018).

26 Directive 2006/116/EC of the European Parliament and of the Council of 12 December 2006 on the term of protection of copyright and certain related rights (codified version), http://eur-lex.europa. eu/legal-content/EN/ALL/?uri=CELEX\%3A32006L0116 (access: 11.02.2018).

27 Directive 96/9/EC of the European Parliament and of the Council of 11 March 1996 on the legal protection of databases, http://eur-lex.europa.eu/LexUriServ/LexUriServ.do?uri=OJ:L:19 96:077:0020:0028:EN:PDF (access: 11.02.2018).

28 Directive 2001/29/EC of the European Parliament and of the Council of 22 May 2001 on the harmonisation of certain aspects of copyright and related rights in the information society, http:// eur-lex.europa.eu/legal-content/EN/ALL/?uri=celex\%3A32001L0029 (access: 11.02.2018).

29 Directive 2001/84/EC of the European Parliament and of the Council of 27 September 2001 on the resale right for the benefit of the author of an original work of art, http://eur-lex.europa.eu/ legal-content/EN/TXT/?uri=CELEX\%3A32001L0084 (access: 11.02.2018). 
(2012), ${ }^{30}$ and Collective Management Directive (2014). ${ }^{31}$ Each of them regulates a different area of copyright protection. However, the very important element of the EU copyright system is currently in force i.e. articles 114 and 118 of TFEU. ${ }^{32}$

It is obvious that if the European Union intends to regulate an area of social order, it must to have a specific legislative competence (it is connected with the principle of conferral of powers). ${ }^{33}$ Unfortunately, in the primary legislation of the EU there are no legal provisions that give competence to the legislative bodies of the EU in the area of copyright protection. ${ }^{34}$ There is only art. 114 (1) of TFEU ${ }^{35}$ which constitutes the competence of the European Union authorities to harmonise national laws. Despite that, this article does not provide instruction what legal measures should be applied by the legislative bodies of the EU to harmonise law of the member states. ${ }^{36}$ This article in the scientific literature is treated as a functional competence of the European Union on the one hand, and as a objective of the European legislature on the other. ${ }^{37}$ This purpose is to create an internal, uniform market of the European Union consisting of markets of the member states. However, art. 114 (1) of TFEU is a very general and abstract legal provision which sets forth a goal but does not provide any guidance how to achieve it. This statement is particularly relevant to copyright protection. However, the Treaty of Lisbon introduces a new article that allows the EU to create European intellectual property rights - it is art. 118 of TFEU that reads as follows:

In the context of the establishment and functioning of the internal market, the European Parliament and the Council, acting in accordance with the ordinary legislative procedure, shall establish measures for the creation of

30 Directive 2012/28/EU of the European Parliament and of the Council of 25 October 2012 on certain permitted use of orphan works Text with EEA relevance, http://eur-lex.europa.eu/legal-content/EN/TXT/?uri=celex\%3A32012L0028 (access: 11.02.2018).

31 Directive 2014/26/EU of the European Parliament and of the Council of 26 February 2014 on collective management of copyright and related rights and multi-territorial licensing of rights in musical works for online use in the internal market Text with EEA relevance, http://eur-lex.europa. eu/legal-content/EN/TXT/?uri=celex\%3A32014L0026 (access: 11.02.2018).

32 The consolidated version of the Treaty on the Functioning of the European Union, http://eur-lex. europa.eu/legal-content/EN/TXT/?uri=celex\%3A12012E\%2FTXT (access: 11.02.2018).

33 See: A. Ramalho, The Competence of the European Union in Copyright Lawmaking. A Normative Perspective of EU Powers for Copyright Harmonization, Springer 2016, p. 9.

34 Ibidem.

35 The consolidated version of the Treaty on the Functioning of the European Union, http://eur-lex. europa.eu/legal-content/EN/TXT/?uri=celex\%3A12012E\%2FTXT (access: 11.02.2018).

36 A. Ramalho, op. cit., p. 11.

37 See: Ibidem, p. 11. 
European intellectual property rights to provide uniform protection of intellectual property rights throughout the Union and for the setting up of centralised Union-wide authorisation, coordination and supervision arrangements.

The Council, acting in accordance with a special legislative procedure, shall by means of regulations establish language arrangements for the European intellectual property rights. The Council shall act unanimously after consulting the European Parliament. ${ }^{38}$

As Ana Ramalho indicated this provision gives a unique chance to create a European uniform copyright right, valid in all European member states. ${ }^{39}$ Such a new pan-European copyright right would take a new form in legal order and it would be a completely different legislative process than harmonisation (harmonisation allows for bringing laws of member states closer). This issue is a very interesting scientific matter, however it goes beyond the scope of this work. It can be only emphasised that such a legal instrument as European uniform copyright title is a much more demanding institution than directives, which only bring legal orders of member states closer. Such a change in the European law requires efficient solutions not only at the legislative level, but also in the governmental sphere where the copyright law will be applied.

The following rights are protected by the European Union copyright law: ${ }^{40}$

$\square$ right of reproduction for authors, performers, producers of phonograms and films and broadcasting organisations (Art. 7 of Directive 92/100/EEC superseded by Art. 2 of Directive 2001/29/EC: ${ }^{41}$ also Art. 14 TRIPS, ${ }^{42}$ Arts. 7 \& $\left.11 \mathrm{WPPT}^{43}\right)$;

right of communication to the public for authors, performers, producers of phonograms and films and broadcasting organisations (Art. 3 Directive 2001/29/EC: also Art. 10 TRIPS, Art. 8 WCT ${ }^{44}$ and Arts. 6, 10 \& 14 WPPT);

38 The consolidated version of the Treaty on the Functioning of the European Union, http://eur-lex. europa.eu/legal-content/EN/TXT/?uri=celex\%3A12012E\%2FTXT (access: 11.02.2018).

39 A. Ramalho, op. cit., p. 10.

40 S. Foreman, op. cit., p. 28.

41 Directive 2001/29/EC of the European Parliament and of the Council of 22 May 2001 on the harmonisation of certain aspects of copyright and related rights in the information society.

42 Agreement on Trade-Related Aspects of Intellectual Property Rights, Source:https://www.wto. org/english/docs_e/legal_e/27-trips_04_e.htm (access: 12.02.2018).

43 WIPO Performances and Phonograms Treaty, Geneva 1996, http://www.wipo.int/wipolex/en/ details.jsp?id=12743 (access: 12.02.2018).

44 WIPO Copyright Treaty, Geneva 1996, http://www.wipo.int/wipolex/en/details.jsp?id=12740 (access: 12.02.2018). 
$\square$ right of distribution for authors (Art. 4, Directive 2001/29/EC) and for performers, producers of phonograms and films and broadcasting organisations (Art. 9 of Directive 92/100/EEC: ${ }^{45}$ also Art. 10 TRIPS, Art. 6 WCT and Arts. 8 \& 12 WPPT);

$\square$ right of preservation for performers and broadcasting organisations (Art. 6 of Directive 92/100/EEC; ${ }^{46}$ also Art. 14 TRIPS and Art. 6 WPPT);

$\square$ right of rent and/or lending;

$\square$ lending for authors, performers, producers of phonograms and films (Art. 2 of Directive 92/100/EEC: also Art. 11 TRIPS, Art. 7 WCT and Arts. $9 \& 13$ WPPT), with an associated right of equitable remuneration for lending and/or rent for authors and performers (Art. 4 of Directive 92/100/EEC);

$\square$ right of broadcasting for performers, producers of phonograms and broadcasting organisations (Art. 8 of Directive 92/100/EEC: also Art. 6 WPPT);

$\square$ right of communication to the public by satellite for authors, performers, producers of phonograms and broadcasting organisations (Arts. 2, 4 of Directive 93/83/EEC ${ }^{47}$;

$\square$ the rights of reproduction, distribution and rent of computer programs for authors are specified in Art. 4 of Directive 91/250/EEC ${ }^{48}$ (also Art. 11 TRIPS).

Having introduced the sources of international law, it is proper to contemplate the philosophy of this branch of law.

\section{Philosophical justification}

It has already been mentioned that bringing the legal systems of the member states in the field of copyright closer is a very difficult task. The reason is that legal systems of the members of the EU differ from one another not only in provisions but

45 The Directive 92/100/EEC is no longer in force, however it corresponds with other cited sources of law.

46 As mentioned above.

47 Council Directive 93/83/EEC of 27 September 1993 on the coordination of certain rules concerning copyright and rights related to copyright applicable to satellite broadcasting and cable retransmission, http://eur-lex.europa.eu/legal-content/EN/ALL/?uri=celex\%3A31993L0083 (access: 12.02.2018).

48 Council Directive 91/250/EEC of 14 May 1991 on the legal protection of computer programs, http:// eur-lex.europa.eu/legal-content/PL/TXT/?uri=CELEX\%3A31991L0250 (access: 12.02.2018); no longer in force (date of end of validity: 24.05.2009), however it corresponds with other cited sources of law. 
especially in the structure of copyright protection..$^{49}$ There are two systems of copyright: ${ }^{50}$

a) the droit d'auteur system,

b) the copyright system.

According to the latter, the majority of the EU national laws operate in accordance with this manner of protection. ${ }^{51}$ However, each of the two systems of copyright protection has its own philosophical (and historical) justification. I hold the view that droit d'auteur is supported in particular by the theory of natural laws; on the other hand the copyright system is primarily established in the utilitarian theory. Both of them are explained below and the analysis of the justification of copyright protection in the international treaties will be carried out duly.

\section{The theory of natural laws}

There are many types of the theory of natural laws in legal and philosophical literature. However, there are two arguments fundamental for the theory of natural laws. ${ }^{52}$ The first one states that the laws are discovered by sources of law, they are not created by them. ${ }^{53}$ The latter states that the natural law „is a set of general moral standards". ${ }^{54}$ Taking the naturalistic point of view on copyrights, there are two theories to explain the existence of copyright protection: ${ }^{55}$

a) John Locke's labour theory,

b) Georg Hegel's personality rights theory.

Locke's labour theory is strongly linked with the concept of property. John Locke mentioned men's "natural" entitlement to the fruit of their labour. ${ }^{56}$ In Locke's philosophy, labour is a factor that creates ownership for the person who made

\section{A. Ramalho, op. cit., p. 2.}

Ibidem.

Ibidem.

52 There are other basic presumptions of the theory of natural laws, in the author's opinion those two are the most important assumptions of this trend.

53 Source: https://www.allaboutphilosophy.org/natural-law.htm (access: 7.02.2018).

54 J. Finnis, Natural Law and Natural Rights, New York 2011, p. 23.

55 A. Ramalho, op. cit., p. 3.

56 K.I. Vaughn, John Locke and the Labour Theory of Value, "Journal of Libertarian Studies" 1978, 4, pp. 311-326, see p. 311. 
something out of nothing only through their work. ${ }^{57}$ In "Second Treatise of Government" he included such concepts on property and ownership:

Though the earth, and all inferior creatures, be common to all men, yet every man has a property in his own person: this nobody has any right to but himself. The labour of his body, and the work of his hands, we may say, are properly his. Whatsoever then he removes out of the state that nature hath provided, and left it in, he hath mixed his labour with, and joined to it something that is his own, and thereby makes it his property. ${ }^{58}$

Thus, John Locke emphasised that common areas and common things are the primal state of the world. Human work is the element that makes a difference and creates the ownership of things not only made from scratch but also extracted from objects previously not belonging to any person. How may this manner of thinking have an impact on rationale of intellectual property rights and consequently - on the existence of copyright protection? As Ana Ramalho shows the thoughts of human minds are commonly owned. Similarly, when a person puts an effort into creating a new concept, this work would result in the ownership of such an idea. ${ }^{59}$ Ramalho indicates that a right to property in such a case is a form of reward for the exertion put into constructing a new idea. This argumentation is very close to the reasoning presented by Wendy Gordon who said that the main problem that intellectual property must face is the compensation for authors to a justifiable extent. ${ }^{60}$

In my opinion it is rather not a type of reward but rather justice. In other words, it is just when a person who used intellectual energy to make something new, becomes the proprietor of this thought. It is also just when the person obtains a whole range of various rights (e.g. the right to use their property). In my opinion, the application of John Locke's labour theory in copyright law is a matter of justice, not a matter of "reward”. The following interesting issue related to the labour theory is the question as to the essence of this approach - whether the work (effort) put into creation of material or intellectual entity is the factor, that makes a difference and entitles the person who created a new thing to be the proprietor of the thing? Libertarian philosophers who represent the axiomatic approach claim that in this

\footnotetext{
57 J. Locke, Second Treatise of Government, Indianapolis-Cambridge 1980, p. 19.

58 Ibidem.

59 A. Ramalho, op. cit., p. 3.

60 W.J. Gordon, On Owning Information: Intellectual Property and the Restitutionary Impulse, "Virginia Law Review" 1992, 149, pp. 149-281; idem, Of Harms and Benefits: Torts, Restitution and Intellectual Property, "Journal of Legal Studies" 1992, 21(2), pp. 449-482.
} 
situation the axiom of the first possession is applied. ${ }^{61}$ They did not refer to the matter of copyright protection, but it seems that axiomatic approach may also be applied in the philosophy of intellectual property. In effect, the person who created a song or novel is its owner not because of the intellectual effort used to create it, but because he is the first holder of this piece. Naturally, there are many ways of explanation how the property is brought into existence, but the matter goes vastly beyond the scope of this article.

As to the personality rights theory M. Kretschmer and F. Kawohl claimed that Hegel understood property as the "manifestation of a personality". ${ }^{2}$ This trend is also called "Personhood Theory" and begins in Immanuel Kant's philosophy which perceived literary works as an inalienable piece of human soul (personality). ${ }^{63}$ This approach is based on the presumption that results of human intellect incorporate and express the personality of their author. ${ }^{64}$ According to this theory, the subject of copyright law simultaneously personifies identity of its author and is also the enlargement of his personality ${ }^{65}$ In other words, this approach focuses on the fact that intellectual works need legal protection. The outcomes of our mind are not tangible things - they are creations of intellect to which human being has relation only through their mind, never through their body in the way they may handle his coat or his money. If a carpenter creates the table, this table is his ownership. Thus, the fact that a song or poem does not exist physically does not mean that the author does not have the ownership of his work. Nowadays there are even more possibilities than ever before to distribute the most famous books or articles illegally. The results of mental activities may be objects of ownership, thanks to which the owner should have all rights that come from his ownership. Finally, all the assumptions that come from the personality rights theory and are the foundation of $r$ copyright protection are the utmost expression of a moral way of the justification of copyright. ${ }^{66}$

What is the evidence that there is a bond between the author and his work? Advocates of this approach claim that the effect of human mind is an „expression

61 H.-H. Hoppe, The Idea of a Private Law Society, https://mises.org/library/idea-private-law-society (access: 12.02.2018).

62 M. Kretschmer, F. Kawohl, The History and Philosophy of Copyright, [in:] Music and Copyright, Edinburgh 2004, p. 30.

63 P.S. Menell, Intellectual Property: General Theories, [in:] Encyclopedia of Law and Economics, http:// reference.findlaw.com/lawandeconomics/1600-intellectual-property-general-theories.pdf (access: 10.02.2018).

64 A. Ramalho, op. cit., p. 4.

65 Ibidem.

66 Ibidem. 
of precisely those slight differences of individual physique, temperament and character which make him a different man from that neighbour" ${ }^{\prime 6}$ In my opinion, it should be said that this element makes each of us unique - each of us is different from billions of other people. Since each of us is an extraordinary individual, therefore fruits of our creation are also uncommon. Creation of human mind is the reflection of an author's personality what constitutes the bond that - is also exceptional. By this assumption of the moral way of thinking about copyright protection its proponents postulate, that by the very nature of justice the author is entitled to have power over the product of either his hand or his brain. Now, it is clear that the author should "have the right to claim authorship of the work and to object to any distortion, mutilation or other modification of, or other derogatory action in relation to, the said work, which would be prejudicial to his honour or reputation" ${ }^{68}$

The final important question is the issue whether these two theories are mutually exclusive. In my opinion - as most of the doctrine's representatives - the true rationale of copyright law (and the whole intellectual property law) is the combination of the two ways of reasoning. Thereby, the copyright system is necessary because intellectual property is a type of reward and justice for a person who creates a new intellectual object. At the same time the personal bond created between the author and his work is the factor that must be protected by legal system.

There is no absolute answer to the question what the philosophical justification of copyright protection is, in relation to international treaties in particular. However, before the author tries to find the answer, it is worth exploring an economic approach.

\section{Utilitarian (economic) approach}

The fundamental assumption of the way of thinking is that the copyright law should be "optimum" which means that legal regulations should constitute a balance between incentives to create a new work and benefits for the whole society. ${ }^{69}$ But what exactly is utilitarianism? Steven Medema accurately described this in the following sentence:

67 E. Bruncken, The Philosophy of Copyright, "The Musical Quarterly" 1916, 3, pp. 477-496, see p. 479.

68 Art. 6bis (1) of the Berne Convention for the Protection of Literary and Artistic Works, http://www. wipo.int/treaties/en/text.jsp?file_id=283698\#P85_10661 (access: 11.02.2018).

69 See A. Ramalho, op. cit., p. 4; see also R. Posner, An Economic Analysis of Copyright Law, "The Journal of Legal Studies" 1989, 2, pp. 325-363. 
In its positive manifestation, utilitarianism describes a psychological propensity - that people make choices with a view to furthering their own utility, or happiness, or excess of pleasure over pain. ${ }^{70}$

Utilitarianism is a philosophical trend founded by Jeremy Bentham and further developed by John Stuart Mill. Its main assumption is the principle of utility defined by Bentham and reads as follows:

By the principle of utility is meant that principle which approves or disapproves of every action whatsoever. According to the tendency it appears to have to augment or diminish the happiness of the party whose interest is in question: or, what is the same thing in other words to promote or to oppose that happiness. I say of every action whatsoever, and therefore not only of every action of a private individual, but of every measure of government. ${ }^{71}$

This quotation shows that the founder of utilitarianism understood the principle of utility as the aggregate of happiness and sadness. It relates to entities and groups of people. Moreover, it can be applied to actions taken by government or by a single person. The utility for the whole society was a very important issue considered by utilitarians (what is also visible in the utilitarian approach to copyright). Bentham explained what the utility of whole communities is in the following terms:

The interest of the community then is, what is it? - the sum of the interests of the several members who compose it. ${ }^{72}$

When we know how Bentham understood the notion of utility of community, in the last step we can take a look at the relations between actions taken by an entity and the welfare of society:

A man may be said to be a partisan of the principle of utility, when the approbation or disapprobation he annexes to any action, or to any measure, is determined by and proportioned to the tendency which he conceives it to have to augment or to diminish the happiness of the community: or in

70 S.G. Medema, Sidgwick's Utilitarian Analysis of Law: A Bridge from Bentham to Becker?, "American Law and Economics Review" 2007, 1, p. 32.

71 J. Bentham, An Introduction to the Principles of Morals and Legislation, Kitchener, Ont. 2000, p. 14.

72 Ibidem, p. 15. 
other words, to its conformity or unconformity to the laws or dictates of utility.

The utilitarian theory in copyright protection boils down to maximizing the utility of the society and simultaneously - to giving as much happiness to the actor as possible. In copyright law the utilitarian rationale is all about incentives: authors should have the motivation to invent something new (i.e. a song, book or other object of copyright protection) and the society should have as wide access to results of human intellect as possible. Why is the balance between those incentives so important? It is due to the fact that human civilization may expand only when each of us can use the results of human mind. The whole science is based on this possibility. Mathematicians, physicists, biologists, philosophers - all of them (and representatives of other branches of science) can make a significant progress in science when they can deliver their research with the application of the latest stage of knowledge. By it, each new generation of scientists may move forward without the need to discover something what has already been discovered. This is the core and the heart of science-making progress, discovering something new, without repeating earlier discoveries. Within the context of the civilisation, lifestyle and values of the society this possibility (i.e. we have access to pieces of work of various artists) is also a very important factor that has a strong impact on the development of culture. The following legal institutions may be exemplary here: the inspired work and the derivative work. These legal instruments were created to legitimize the flow of creative ideas between and among artists. Mutual inspiration is something unavoidable in the culture and art. Thus, copyright law should meet expectations and requirements of artists on the one hand, and challenges of the modern world on the other.

Economic thinking about copyright focuses on costs that are a very important aspect of creative activity. This way of reasoning perfectly describes relationship between costs incurred by authors and return gained by them. However, all human activity comes down to such an equation. Financial return is the measure which allows people to lead a quiet (or even dream) life. The economic approach focuses on the costs that the author has to bear in order to invent a new intellectual object. ${ }^{73}$ They are called "costs of expressions" and they consist of the author's time and effort applied to create an object of copyright protection. Costs of publisher are also included (i.e. costs of editing and marketing). ${ }^{74}$ Posner indicates that the author creates a piece of intellectual work only when his expected return exceeds expected

\footnotetext{
73 R. Posner, op. cit., p. 327.

74 Ibidem.
} 
costs. ${ }^{75}$ Moreover, the costs of copies are far lower than initial costs borne by the author and inventor who want to make profits from somebody else's work is in the privileged position. ${ }^{76}$ Thus, the economic analysis of copyright (which is very a complex and developed branch of theory and philosophy of law) aims to construct such legal provisions that will - on the one hand - defend the author's interests, and on the other stimulate scientific and cultural progress. This shows the importance of economic analysis of law for everyday application of copyright law. The most valuable work in the field seems to be Richard Posner's and William Landes' article titled Economic Analysis of Copyright Law (included in the bibliography).

It is possible to refer to various philosophical theories used to justify copyright protection. There are Positive Analysis of Intellectual Property Protection, Libertarian Theories, Theories of Distributive Justice, Democratic Theories, Socialist Theories and Ecological Theories. ${ }^{77}$ However, in my opinion, only two ways of justification of copyright protection influenced the shape of international law. They are referred to as Personhood Theory and utilitarian (economic) approach.

\section{The application of philosophical justification in international treaties}

There are basic economic presumptions that underlie legal framework of international treaties and the EU law. The shape of legal regulations of international treaties and the EU law was created to encompass the interests of authors. For instance, the reflection of the economic assumptions is contained in Recital 10 of the Directive 2001/29/EC. It reads as follows:

If authors or performers are to continue their creative and artistic work, they have to receive an appropriate reward for the use of their work, as must producers in order to be able to finance this work. (...) Adequate legal protection of intellectual property rights is necessary in order to guarantee the availability of such a reward and provide the opportunity for satisfactory returns on this investment. ${ }^{78}$

75 Ibidem.

76 W.J. Gordon, R.G. Bone, Copyright, [in:] Encyclopedia of Law and Economics, p. 192, http://reference. findlaw.com/lawandeconomics/1610-copyright.pdf (access: 10.02.2018).

77 See: P.S. Menell, op. cit., pp. 155-156, 159-163.

78 Directive 2001/29/EC of the European Parliament and of the Council of 22 May 2001 on the harmonisation of certain aspects of copyright and related rights in the information society, http:// eur-lex.europa.eu/legal-content/EN/ALL/?uri=celex\%3A32001L0029 (access: 11.02.2018). 
Legal institutions that allow to fully implement these economic assumptions are economic copyrights. These rights are set forth in article 2 of the Directive 2001/29/EC which contains the author's reproduction right. This is the basic economic copyright which meets not only the above mentioned requirements of economic analysis but also corresponds with the justification that there is a specific bond between the author and their work. Relating to economic efficiency the right is a tool through which the author can generate income. However, this is not the only economic right of the author expressed in the EU law. Article 3 of the same Directive sets forth a right of communication of a piece of work to the public and a right of making any other subject matter available to the general public. In turn art. 4 of the Directive contains a distribution right. Through the legal powers, authors have exclusive right to authorise or prohibit any form of distribution to the public by sale or otherwise. This is also a measure that has economic rationale but definitely it is more of the reflection of Personhood Theory. As intellectual pieces of work are a part of their author, the author should have legal power to authorise the distribution of their work to the general public. The same is introduced in art. 9 (1) of the Berne Convention stating that authors of literary work have also the exclusive right of authorising the reproduction of their works. Moreover, art. 11 (1) (i) and (ii) states out authors' (more precisely: authors of dramatic, drama and musical and musical works) the exclusive right of authorising the public performance of their works, including public performance by any manner. The authors also have a right to any communication to the general public of the performance of their works. In turn, articles 11 (1) (i) and (ii) state that authors of literary works have the exclusive right to authorise the public recitation of their works, including such public recitation by any means or process and any communication to the public of the recitation of their works.

The aforementioned right of rental and/or lending for authors, performers, producers of phonograms and films included in already expired art. 2 of Directive 92/100/EEC (but also present in art. 11 of TRIPS) is confirmation of economic and natural justification of copyright. The right helps creators to receive return and simply follows the thought that there is a specific bond between the author and their work. Thereby, what is stated above pertains to the right of broadcasting for performers, producers of phonograms and broadcasting organisations (Art. 6 WPPT), the right of communication to the public by satellite for authors, performers, producers of phonograms and broadcasting organisations (Arts. 2, 4 of Directive 93/83/ EEC), and rental right for authors of computer programs which is specified in art. 11 of TRIPS.

The right of adaptation, arrangement and other changes that authors of literary and artistic works are entitled to is set forth in art. 12 of the Berne Convention. 
The other exclusive rights are contained in art. 14 (1) (i) and (ii). There are incorporated exclusive rights (vested in authors of literary or artistic works) of authorising: the cinematographic adaptation and reproduction of the works, and the distribution of the works thus adapted or reproduced; the public performance and communication of the works thus adapted or reproduced by wire to the public. Finally, it is important to mention art. 14 (1) which covers the author's droit de suite. This right is granted to artists or their heirs to receive a fee on the resale of their works of art.

To sum up it, Berne Convention, the EU law and the other abovementioned sources of international law provide a legal regulation that satisfies the requirements not only of economic efficiency but also the requirements of Personhood Theory.

\section{Universalistic approach}

It is worth emphasizing that the World Intellectual Property Organisation is pure embodiment of this philosophical trend advocating for a universalistic form of legal framework of copyright protection. Under Article 3 of the Convention Establishing the World Intellectual Property Organization, ${ }^{79}$ WIPO seeks to "promote the protection of intellectual property throughout the world". It is responsible for promoting creative intellectual activity in order to accelerate economic, social and cultural development. The objectives and subjects of copyright law are the same in the whole world, thus the legal protection of intellectual property should be equal everywhere. Art. 114 of TFEU is the reflection of the tendency to unify the systems of law of the member states of the EU. Hence, it is justified to say that it is the manifestation of universalistic movement that aimed to apply the copyright law as widely as possible. Moreover, the EU not only tries to spread the idea of copyright protection but also tries to apply it in all the member states in the same form.

\section{Conclusions}

At present international copyright law is a very wide and complex branch of law. Because WIPO international treaties, the Berne Union or legal systems of the whole European Union are in force. It must be also admitted that a very long and difficult process leading the global society to enact legal protection of copyright is required. As it has been presented, before signing the Berne Convention in 1886 there had been a number of negotiations between and among many countries. Then the Convention

79 Convention establishing the World Intellectual Property Organization, Stockholm 1967, http:// www.wipo.int/treaties/en/convention/ (access: 12.02.2018). 
was revised a few times in order to adapt to different social and technological conditions. In my opinion, a good copyright law should be adaptable to ever-changing and demanding technological circumstances. It is worth realising that the need to regulate the copyright law was created almost immediately, when people began to save their thoughts on durable things. As it has been mentioned, there are two different trends that justify rightness of copyright protection. The economic one focuses on economic efficiency and tries to provide the optimum ground between the author's and social interests. On the other hand, the Personhood Theory illustrates that there is a specific bond between the author and their work and this is the main reason of legal protection. Normative acts now in force establish a range of economic and personal copyrights that are vested in the author. As far as my opinion is concerned, the current legal framework is good, nevertheless the lawmaker should take the changing environment into account and thus it should adapt (whether it is necessary) legal copyright regulations to new conditions.

\section{Bibliography}

Agreement on Trade-Related Aspects of Intellectual Property Rights, https://www. wto.org/english/docs_e/legal_e/27-trips_04_e.htm (access: 12.02.2018).

Bentham J., An Introduction to the Principles of Morals and Legislation, Kitchener, Ont. 2000.

Bruncken E., The Philosophy of Copyright, "The Musical Quarterly" 1916, 3, pp. 477-496. Convention establishing the World Intellectual Property Organization, Stockholm 1967, http://www.wipo.int/treaties/en/convention/ (access: 12.02.2018).

Council Directive 91/250/EEC of 14 May 1991 on the legal protection of computer programs, http://eur-lex.europa.eu/legal-content/PL/TXT/?uri=CELEX\%3A31991L0250 (access: 12.02.2018).

Council Directive 93/83/EEC of 27 September 1993 on the coordination of certain rules concerning copyright and rights related to copyright applicable to satellite broadcasting and cable retransmission, http://eur-lex.europa.eu/legal-content/EN/ALL/?uri$=$ celex\%3A31993L0083 (access: 12.02.2018).

Directive 2001/29/EC of the European Parliament and of the Council of 22 May 2001 on the harmonisation of certain aspects of copyright and related rights in the information society, http://eur-lex.europa.eu/legal-content/EN/ALL/?uri=celex\%3A32001L0029 (access: 11.02.2018).

Directive 2001/84/EC of the European Parliament and of the Council of 27 September 2001 on the resale right for the benefit of the author of an original work of art., http:// eur-lex.europa.eu/legal-content/EN/TXT/?uri=CELEX\%3A32001L0084 (access: 11.02.2018). 
Directive 2006/115/EC of the European Parliament and of the Council of 12 December 2006 on rental right and lending right and on certain rights related to copyright in the field of intellectual property (codified version), http://eur-lex.europa.eu/legal-content/EN/ALL/?uri=CELEX\%3A32006L0115 (access: 11.02.2018).

Directive 2006/116/EC of the European Parliament and of the Council of 12 December 2006 on the term of protection of copyright and certain related rights (codified version), http://eur-lex.europa.eu/legal-content/EN/ALL/?uri=CELEX\%3A32006L0116 (access: 11.02.2018).

Directive 2009/24/EC of the European Parliament and of the Council of 23 April 2009 on the legal protection of computer programs (codified version), http://eur-lex.europa. eu/legal-content/EN/ALL/?uri=CELEX\%3A32009L0024 (access: 11.02.2018).

Directive 2012/28/EU of the European Parliament and of the Council of 25 October 2012 on certain permitted uses of orphan works Text with EEA relevance, http://eur-lex. europa.eu/legal-content/EN/TXT/?uri=celex\%3A32012L0028 (access: 11.02.2018).

Directive 2014/26/EU of the European Parliament and of the Council of 26 February 2014 on collective management of copyright and related rights and multi-territorial licensing of rights in musical works for online use in the internal market Text with EEA relevance, http://eur-lex.europa.eu/legal-content/EN/TXT/?uri=celex\%3A32014L0026 (access: 11.02.2018).

Directive 96/9/EC of the European Parliament and of the Council of 11 March 1996 on the legal protection of databases, http://eur-lex.europa.eu/LexUriServ/LexUriServ. do? uri=OJ:L:1996:077:0020:0028:EN:PDF (access: 11.02.2018).

Finnis J., Natural Law and Natural Rights, New York 2011.

Foreman S., Copyright Law: World Study, Delhi 2012.

Goldstein P., International Copyright: Principles, Law, and Practice, Oxford 2001.

Gordon W.J., Of Harms and Benefits: Torts, Restitution and Intellectual Property, "Journal of Legal Studies" 1992, 21(2), pp. 449-482.

Gordon W.J., On Owning Information: Intellectual Property and the Restitutionary Impulse, "Virginia Law Review" 1992, 149, pp. 149-281.

Gordon W.J., Bone R.G., Copyright, [in:] Encyclopedia of Law and Economics, http://reference. findlaw.com/lawandeconomics/1610-copyright.pdf (access: 10.02.2018).

Hoppe H.-H., The Idea of a Private Law Society, https://mises.org/library/idea-private-law-society (access: 12.02.2018).

https://www.allaboutphilosophy.org/natural-law.htm (access: 7.02.2018).

Kretschmer M., Kawohl F., The History and Philosophy of Copyright, [in:] Music and Copyright, Edinburgh 2004.

Locke J., Second Treatise of Government, Indianapolis-Cambridge 1980.

Medema S.G., Sidgwick's Utilitarian Analysis of Law: A Bridge from Bentham to Becker?, "American Law and Economics Review" 2007, 1.

Menell P.S., Intellectual Property: General Theories, [in:] Encyclopedia of Law and Economics, http://reference.findlaw.com/lawandeconomics/1600-intellectual-property-generaltheories.pdf (access: 10.02.2018). 
Posner R., An Economic Analysis of Copyright Law, "The Journal of Legal Studies" 1989, 2, pp. 325-363.

Ramalho A., The Competence of the European Union in Copyright Lawmaking. A Normative Perspective of EU Powers for Copyright Harmonization, Springer 2016.

The Berne Convention for the Protection of Literary and Artistic Works, http://www. wipo.int/treaties/en/text.jsp?file_id=283698\#P85_10661 (access: 11.02.2018)

The consolidated version of the Treaty on the Functioning of the European Union, http:// eur-lex.europa.eu/legal-content/EN/TXT/?uri=celex\%3A12012E\%2FTXT (access: 11.02.2018).

Universal Copyright Convention as revised at Paris on 24 July 1971, with Appendix Declaration relating to Article XVII and Resolution concerning Article XI 1971, http:// portal.unesco.org/en/ev.php URL_ID=15241\&URL_DO=DO_TOPIC\&URL_SECTION=201.html (access: 11.02.2018).

Vaughn K.I., John Locke and the Labour Theory of Value, "Journal of Libertarian Studies" 1978, 4, pp. 311-326.

WIPO Copyright Treaty, Geneva 1996, http://www.wipo.int/wipolex/en/details.jsp?id=12740 (access: 12.02.2018).

WIPO Performances and Phonograms Treaty, Geneva 1996, http://www.wipo.int/wipolex/ en/details.jsp?id=12743 (access: 12.02.2018). 